\title{
Studies on the Teratogenicity of Food Additives (2)
}

\author{
Effects of Cyclohexylamine and Cyclohexylamine Sulfate on the \\ Fetal Development in Rats
}

(Received August 2, 1973)

\begin{abstract}
Satoru TANAKA, Shinsuke NAKAURA, Kunio KAWASHIMA, Shigeyuki NAGAO, Tsukasa KUWAMURA and Yoshihito OMORI
\end{abstract}

(Department of Pharmacology, National Institute of Hygienic Sciences: 18-1, Kamiyoga 1-chome, Setagaya-ku, Tokyo)

The teratogenic effects of cyclohexylamine (CHA) and cyclohexylamine sulfate (CHAsulfate) were examined in rats. The results obtained were as follows:

Adult Wistar strain female and male rats and Wistar-Imamichi strain non-pregnant and pregnant female rats were orally given aqueous solution of CHA. Acute toxic symptoms caused by CHA were staggering gait; salivation, lacrymation and convulsion. In postmortem examination, remarkable hemorrhage in lung, marked edematous change in the mucous membrane of fore-stomach and congestion in glandural-stomach and duodenum were observed.

Median lethal doses calculated following oral administration of CHA were $236.6 \mathrm{mg} / \mathrm{kg}$, $278.2 \mathrm{mg} / \mathrm{kg}$ for Wistar strain female and male rats, $155.7 \mathrm{mg} / \mathrm{kg}$ for Wistar-Imamichi strain female rats and $180.1 \mathrm{mg} / \mathrm{kg}$ for pregnant Wistar-Imamichi rats, respectively.

Pregnant Wistar-Imamichi strain rats were orally given once daily for 7 days from day 7 to 13 of gestation at the doses of $1.8,3.6,18$ and $36 \mathrm{mg} / \mathrm{kg}$ of CHA and its sulfate of $71.6 \mathrm{mg} / \mathrm{kg}$.

In the highest dose of CHA, a suppression in body weight gain and reduction in food and water consumptions were observed and 2 of 17 dams died following the administration. No significant difference between the treated and control groups was found in maintenance of pregnancy and in fetal development, and no abnormalities of the fetuses such as resorption and malformation were observed in all groups.

Cyclamate had been widely used as a noncalorigenic sweetening agent, but recent investigations have revealed that cyclamate was carcinogenic in the bladder of mice ${ }^{1)}$ or rats $^{2)}$ and cytotoxic in human cell cultures ${ }^{8), 4)}$. Tanaka ${ }^{(3), 0)}$ reported that the oral dose of 62.5 $\mathrm{mg} / \mathrm{kg}$ as far smaller as $1 / 200$ of median lethal dose of sodium cyclamate to dam was effective to kill embryos and to retard fetal development when was given only once during the critical stage of gestation.

Kojima and Ichibagase ${ }^{7)}$ also proved that cyclohexylamine (CHA) is a metabolite of sodium cyclamate in urine and feces of human beings and dogs ingested the sweetener. A large number of investigators confirmed the findings of Kojima and Ichibagase ${ }^{8)-16)}$. There are some evidences that $\mathrm{CHA}$ has a mutagenic effect.
The dose-response relationship was observed in the occurrence of spermatogonial or bone marrow cells with chromosomal breaks and gaps in rats treated with parenteral $\mathrm{CHA}^{17)}$, and such chromosomal damages are induced in human leucocyte cultures in vitros). In addition, Pitkin et al. ${ }^{18)}$ demonstrated that CHA could be freely transfered across placental barrier in rhesus monkeys.

These findings suggest a possibility of embryotoxic or teratogenic effects of CHA and the present study was carried out.

\section{Materials and Methods}

In the acute toxicity studies, 10 rats of both sexes of Wistar strain and Wistar-Imamichi strain female weighing 170 to $290 \mathrm{~g}$ in each dose were used. 
CHA was orally given as $10 \%$ aqueous solution through a stomach tube, and $\mathrm{LD}_{00}$ was calculated in male and non-pregnant rats by the method of Litchfield-Wilcoxon ${ }^{10)}$ after 1 week and after 4 days by up and down method in pregnant rats.

In the experiment for teratogenicity of $\mathrm{CHA}$ and CHA-sulfate, Wistar-Imamichi strain rats of 12 to 14 weeks of age were used. The rats were housed individually and given laboratory chow (Oriental Yeast Co. Ltd., Tokyo) and tap water ad libitum in an air-conditioned room kept at $25 \pm 2^{\circ}$ and humidity of 50 to $60 \%$. Primiparous females were mated with males overnight. The rats with sperm in vaginal smear at the next morning were taken to be on day zero of gestation.

Pregnant rats consist of 15 in each group received CHA at doses of $1.8,3.6,18$ and 36 $\mathrm{mg} / 4 \mathrm{ml} / \mathrm{kg}$ daily and another 5 pregnant rats received $71.6 \mathrm{mg} / 4 \mathrm{ml} / \mathrm{kg}$ of CHA-sulfate, which is equivalent to $36 \mathrm{mg} / \mathrm{kg}$ of CHA as base, through a stomach tube once daily for 7 days from day 7 to 13 of gestation. Relevant doses were selected on the bases of the results obtained from another 2 weeks daily administration study and oral acute toxicity studies in pregnant rats on day 16 of gestation.

The fetuses were removed from uterus under ether anesthesia on day 20 of gestation. Implantation site and the number of live and dead fetuses were checked. Live fetuses were weighed, body and tail lengths were measured and external malformations were examined, then they were fixed in $70 \%$ alcohol solution for 1 week. About one third of fixed fetuses were chosen at random from each dam and examined for internal organ malformations by Wilson's method ${ }^{20)}$. The remained fetuses were stained with alizarin red $\mathbf{S}^{21)}$ for skeletal examinations.

\section{Results}

\section{Acute toxicity studies}

No strain and sex differences were found in the development of toxic symptoms except mating behavior was observed in male rats, and also between the pregnant and nonpregnant. The symptoms observed commonly were staggering gait, salivation, hemorrhagic lachrymation and convulsion. The death was followed by respiratory arrest.

In postmortem examination, many round edematous sites of various size in the mucous membrane of the fore-stomach and congestion in the glandural-stomach and duodenum and striking hemorrhage in the lungs were found, but no remarkable changes in other organs were observed. In the examination of survived rats after 1 week of the administration of CHA, hemorrhagic scar in the lungs and thickening in the stomach and duodenal mucosa were observed in all animals examined, except the lowest dose group.

Median lethal doses calculated were shown in Table 1. $\mathrm{LD}_{\mathrm{b0}}$ of Wistar strain female was lower than that of male of the same strain, but higher than that of non-pregnant WistarImamichi strain female. There was no significant difference between the both $\mathrm{LD}_{\mathrm{b} 0}$ of female and male of Wistar strain, but between nonpregnant Wistar strain female and WistarImamichi strain female, a strain-difference was recognized at the level of $p=0.05$. In pregnant Wistar-Imamichi strain, its $\mathrm{LD}_{s 0}$ was somewhat higher than that of non-pregnant same strain female, though the method of caluculation was different.

\section{Teratogenicity studies}

\section{2-1) Effect on dams}

With the daily doses of $1.8,3.6$ and $18 \mathrm{mg} / \mathrm{kg}$ of CHA, the mean body weight gain and food and water consumptions of the dams during

Table 1. Median Lethal Doses of CHA Oral Administration in Rats

Animals

Wistar strain (female)

Wistar strain (male)

Wistar-Imamichi strain (female)

Pregnant

Wistar-Imamichi strain
$\mathrm{LD}_{\mathrm{bo}}$

$236.6 \mathrm{mg} / \mathrm{kg}$

$278.2 \mathrm{mg} / \mathrm{kg}$

$155.7 \mathrm{mg} / \mathrm{kg}$

$180.1 \mathrm{mg} / \mathrm{kg}$
Range

$219.2 \sim 255.6 \mathrm{mg} / \mathrm{kg}$

$250.8 \sim 309.0 \mathrm{mg} / \mathrm{kg}$

$143.4 \sim 167.2 \mathrm{mg} / \mathrm{kg}$

$136.4 \sim 237.7 \mathrm{mg} / \mathrm{kg}$ 


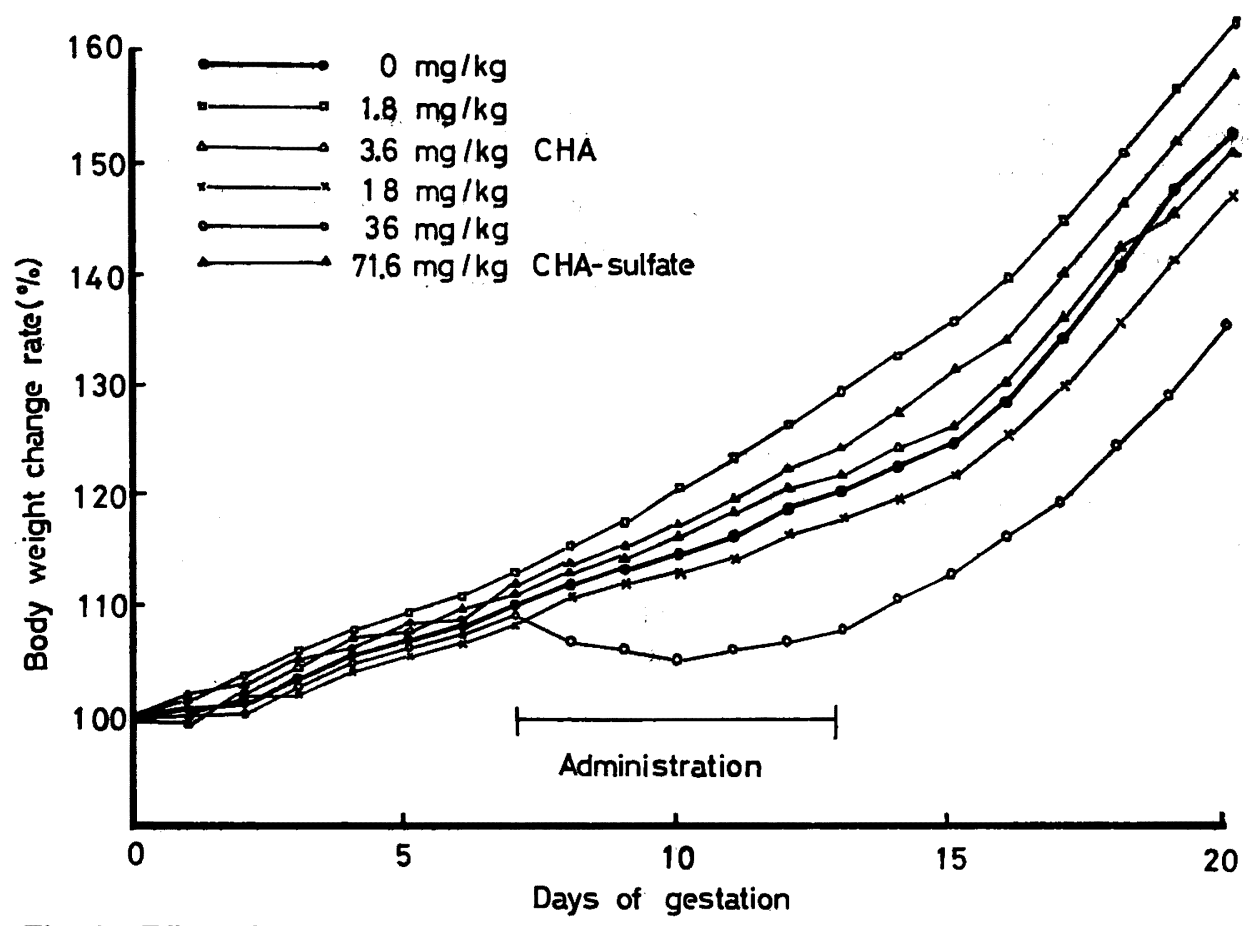

Fig. 1. Effect of oral administration of CHA and CHA-sulfate on body weight changes in pregnant rats

The dose of $71.6 \mathrm{mg} / \mathrm{kg}$ of CHA-sulfate is equivalent to $36 \mathrm{mg} / \mathrm{kg}$ of CHA as base.

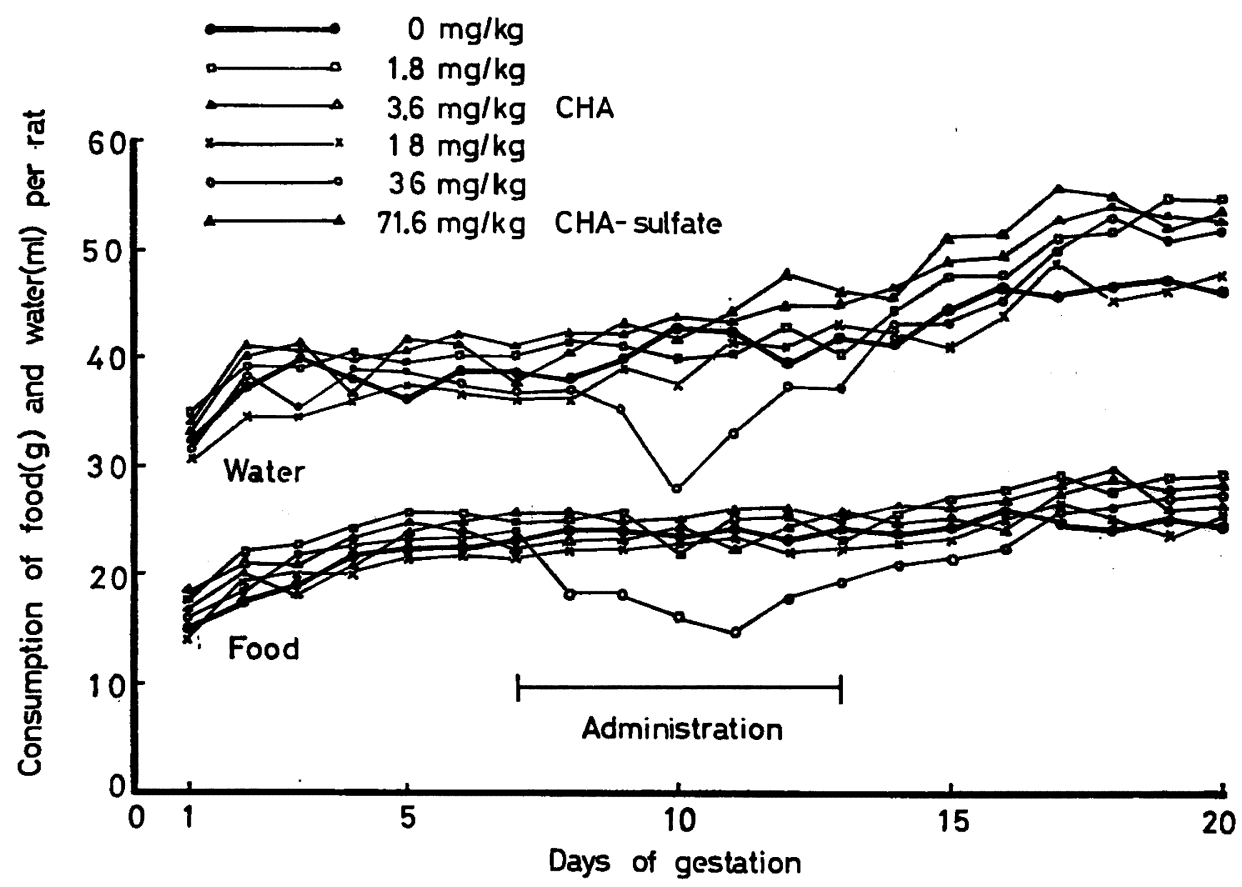

Fig. 2. Effect of oral administration of $\mathrm{CHA}$ and $\mathrm{CHA}$-sulfate on food and water consumptions in pregnant rats

The dose of $71.6 \mathrm{mg} / \mathrm{kg}$ of CHA-sulfate is equivalent to $36 \mathrm{mg} / \mathrm{kg}$ of CHA as base. 
Table 2. Effect of Oral Administration of CHA and CHA-sulfate on Pregnant Rats

\begin{tabular}{|c|c|c|c|c|c|c|}
\hline \multirow{2}{*}{$\begin{array}{l}\text { Treatments } \\
\text { Doses (mg/kg) }\end{array}$} & \multirow{2}{*}{$\begin{array}{c}\text { Control } \\
0 \\
\end{array}$} & \multicolumn{4}{|c|}{$\mathrm{CHA}$} & \multirow{2}{*}{$\frac{\text { CHA-sulfate }}{71.6}$} \\
\hline & & 1.8 & 3.6 & 18 & 36 & \\
\hline No. of rats & 15 & 15 & 15 & 15 & 15 & 5 \\
\hline Uterus weight (g) & $63.6 \pm 3.3$ & $66.1 \pm 2.5$ & $67.6 \pm 2.7$ & $63.9 \pm 2.5$ & $59.7 \pm 2.6$ & $65.4 \pm 3.5$ \\
\hline No. of corpora lutea & $20.2 \pm 0.9$ & $21.2 \pm 1.0$ & $22.3 \pm 0.4$ & $19.9 \pm 0.8$ & $19.7 \pm 0.5$ & $16.0 \pm 0.6$ \\
\hline No. of implantation & $13.4 \pm 0.5$ & $13.3 \pm 0.5$ & $14.5 \pm 0.5$ & $12.9 \pm 0.5$ & $12.3 \pm 0.4$ & $12.6 \pm 0.4$ \\
\hline Rate of nidation (\%) & 66.3 & 62.7 & 65.2 & 64.9 & 62.4 & 78.8 \\
\hline \multicolumn{7}{|l|}{ Placenta } \\
\hline Weight (g) & $0.41 \pm 0.01$ & $0.39 \pm 0.01$ & $0.42 \pm 0.01$ & $0.42 \pm 0.01$ & $0.42 \pm 0.01$ & $0.40 \pm 0.01$ \\
\hline Retention & $7(3.5)$ & $12(6.5)$ & $27(13.9)$ & $14(6.5)$ & $15(7.5)$ & $2(2.5)$ \\
\hline
\end{tabular}

Numerals in The Table indicate the mean \pm standard error and in parentheses the ratio (\%) to total implants.

The dose of $71.6 \mathrm{mg} / \mathrm{kg}$ of CHA-sulfate is equivalent to $36 \mathrm{mg} / \mathrm{kg}$ of CHA as base.

pregnancy were comparable to those of the control, but at the highest dose of $36 \mathrm{mg} / \mathrm{kg}$ of CHA, a considerable suppression in those three parameters was observed following the commencement of the administration (Figs. 1 and 2). In 4 of 17 dams received the highest dose of CHA, salivation was observed after the administration and 2 of them died after 5 days of the administration. The findings in postmortem examination of these dead rats resembled to those found in the oral acute toxicity studies. In the dams survived in this group, however, their body weight began to regain and the food and water consumptions maintained well with the cease of the administration of $\mathrm{CHA}$, and other remarkable toxic symptoms were not observed until day 20 of gestation. At the dose of $71.6 \mathrm{mg} / \mathrm{kg}$ of CHAsulfate, the maternal weight gain and food and water consumptions were comparable to those of the control, and also any toxic symptoms were not observed.

Findings after sacrifice on day 20 of gestation are shown in Table 2. No significant difference between the treated and control groups was found among the uterus weight with fetuses, the placental weight, the numbers of corpora lutea or implantation and the rate of nidation, except the group received CHA-sulfate in which the number of corpora lutea shawed lower value than those of other groups but the value was within the range of cumulative

Table 3. Effect of Maternal Oral Administration of CHA and CHA-sulfate on Embryonic Development in Rats

\begin{tabular}{|c|c|c|c|c|c|c|}
\hline \multirow{2}{*}{$\begin{array}{l}\text { Treatments } \\
\text { Doses }(\mathrm{mg} / \mathrm{kg})\end{array}$} & \multirow{2}{*}{$\frac{\text { Control }}{0}$} & \multicolumn{4}{|c|}{ CHA } & \multirow{2}{*}{$\frac{\text { CHA-sulfate }}{71.6}$} \\
\hline & & 1.8 & 3.6 & 18 & 36 & \\
\hline No. of dams & 15 & 15 & 15 & 15 & 15 & 5 \\
\hline \multicolumn{7}{|l|}{ Alive fetuses } \\
\hline Litter size & $12.7 \pm 0.5$ & $12.3 \pm 0.4$ & $12.3 \pm 0.5$ & $12.0 \pm 0.5$ & $11.1 \pm 0.6$ & $12.2 \pm 0.6$ \\
\hline Body weight (g) & $3.60 \pm 0.01$ & $3.57 \pm 0.02$ & $3.55 \pm 0.02$ & $3.52 \pm 0.05$ & $3.51 \pm 0.03$ & $3.51 \pm 0.06$ \\
\hline Body length (cm) & $3.87 \pm 0.01$ & $3.91 \pm 0.01$ & $3.83 \pm 0.01$ & $3.87 \pm 0.02$ & $3.85 \pm 0.01$ & $3.86 \pm 0.01$ \\
\hline Tail length (cm) & $1.35 \pm 0.01$ & $1.33 \pm 0.01$ & $1.33 \pm 0.01$ & $1.33 \pm 0.01$ & $1.33 \pm 0.01$ & $1.31 \pm 0.01$ \\
\hline No. of malformed fetuses & 0 & 0 & 0 & $3(1.4) *$ & 0 & 0 \\
\hline \multicolumn{7}{|l|}{$\begin{array}{l}\text { No. of malrormed retuses } \\
\text { Dead fetuses }\end{array}$} \\
\hline No. of dead fetuses & $10(5.0)$ & $16(8.8)$ & $30(15.5)$ & $14(6.5)$ & $18(9.0)$ & $2(2.5)$ \\
\hline Resorbed & $3(1.5)$ & $4(2.2)$ & $3(1.5)$ & 0 & $3(1.5)$ & $2(2.5)$ \\
\hline Retained placenta & $7(3.5)$ & $12(6.5)$ & $27(13.9)$ & $14(6.5)$ & $15(7.5)$ & 0 \\
\hline
\end{tabular}

Numerals in the Table indicate the mean \pm standard error and in parentheses the ratio (\%) to total implants.

The dose of $71.6 \mathrm{mg} / \mathrm{kg}$ of CHA-sulfate is equivalent to $36 \mathrm{mg} / \mathrm{kg}$ of $\mathrm{CHA}$ as base.

* Subcutaneous hematocele 
Table 4. Effect of Maternal Oral Administration of CHA and CHA-sulfate on Skeletal Development in Fetal Rats

\begin{tabular}{|c|c|c|c|c|c|c|}
\hline \multirow{2}{*}{$\begin{array}{l}\text { Treatments } \\
\text { Doses }(\mathrm{mg} / \mathrm{kg})\end{array}$} & \multirow{2}{*}{$\frac{\text { Control }}{0}$} & \multicolumn{4}{|c|}{ CHA } & \multirow{2}{*}{$\frac{\text { CHA-sulfate }}{71.6}$} \\
\hline & & 1.8 & 3.6 & 18 & 36 & \\
\hline \multicolumn{7}{|c|}{ No. of fetuses examined } \\
\hline & 124 & 117 & 115 & 123 & 118 & 31 \\
\hline \multicolumn{7}{|c|}{ No. of fetuses with 14 th rib } \\
\hline & $3(2.4)$ & $3(2.6)$ & $4(3.5)$ & $4(3.2)$ & $2(1.7)$ & $2(6.3)$ \\
\hline \multicolumn{7}{|c|}{ No. of fetuses with lacked or deformed sternebrae } \\
\hline & $76(61.3)$ & $89(76.1)$ & $82(71.3)$ & $88(71.5)$ & $89(66.9)$ & $16(51.6)$ \\
\hline \multicolumn{7}{|c|}{ No. of metacarpus } \\
\hline Left 3 & $36(29.0)$ & $30(25.6)$ & $33(28.8)$ & $38(30.9)$ & $32(27.1)$ & $7(22.6)$ \\
\hline 4 & $88(71.0)$ & $87(74.4)$ & $82(71.2)$ & $85(69.1)$ & $86(72.9)$ & $23(77.4)$ \\
\hline Right 3 & $35(28.2)$ & $31(26.5)$ & $33(28.8)$ & $38(30.9)$ & $33(28.0)$ & $7(22.6)$ \\
\hline 4 & $89(71.8)$ & $86(73.5)$ & $82(71.2)$ & $85(69.1)$ & $85(72.0)$ & $23(77.4)$ \\
\hline \multicolumn{7}{|c|}{ No. of metatarsus } \\
\hline Left 3 & $1(0.8)$ & $2(1.7)$ & 0 & $1(0.8)$ & 0 & 0 \\
\hline 4 & $123(99.2)$ & $115(98.3)$ & $115(100)$ & $122(99.2)$ & $118(100)$ & $31(100)$ \\
\hline Right 3 & $1(0.8)$ & $2(1.7)$ & 0 & $1(0.8)$ & 0 & 0 \\
\hline 4 & $123(99.2)$ & $115(98.3)$ & $115(100)$ & $122(99.2)$ & $118(100)$ & $31(100)$ \\
\hline \multicolumn{7}{|c|}{ No. of coccygeal vertebrae } \\
\hline 1 & 0 & 0 & 0 & 0 & 0 & 0 \\
\hline 2 & $1(0.8)$ & $5(4.3)$ & $3(2.6)$ & $3(2.4)$ & $3(2.5)$ & 0 \\
\hline 3 & $30(24.2)$ & $29(24.8)$ & $24(20.9)$ & $29(23.6)$ & $27(22.9)$ & $3(9.8)$ \\
\hline 4 & $78(62.9)$ & $68(58.2)$ & $76(66.1)$ & $79(64.2)$ & $69(58.5)$ & $19(61.3)$ \\
\hline 5 & $13(10.5)$ & $14(12.0)$ & $11(9.6)$ & $12(9.6)$ & $17(14.4)$ & $7(22.6)$ \\
\hline 6 & $2(1.6)$ & $1(0.8)$ & $1(0.9)$ & 0 & $2(1.7)$ & $2(6.3)$ \\
\hline
\end{tabular}

Numerals in parentheses indicate the ratio (\%) to the total fetuses examined.

The dose of $71.6 \mathrm{mg} / \mathrm{kg}$ of CHA-sulfate is equivalent to $36 \mathrm{mg} / \mathrm{kg}$ of CHA as base.

control level in our laboratory.

Although somewhat high placental retentions were noticed in CHA groups, but were not dose-dependent.

\section{2-2) Effect on fetuses}

The mean litter size was almost same in all groups, and no remarkable increase in mortality and retardation in fetal development by the treatment with CHA or its sulfate were observed as shown in Table 3. No marked external or internal organ malformations were observed in all groups, except 3 fetuses with subcutaneous hematocele obtained from one dam in the group of $18 \mathrm{mg} / \mathrm{kg}$ of CHA.

The results obtained in the examination for skeletal system were shown in Table 4. Little deformities of skeleton were found except a few fetuses with 14th rib, and also no marked differences were observed in the shapes and stainings of sternebrae and in the number of metacarpus, metatarsus and coccygeal vertebrae compared with those of the control.

\section{Discussion}

Toxic symptoms and remarkable hemorrhage in lungs as postmortem findings observed in the present acute toxicity studies of CHA have been also reported by Kase et al. ${ }^{22)}$ and Lomonova ${ }^{28)}$, but edematous changes in forestomach and congestion in glandural-stomach and duodenum have not been described in their reports where CHA-sulfate was orally given to rats. In our preliminary experiments such changes in stomach and duodenum did not occur after neutralization of CHA or with a solution of sodium hydroxide with $\mathrm{pH} 12.1$ equal to that of CHA before neutralization. Moreover, the injuries have not been observed with the salts ${ }^{22)}$,28) as in the present experiment using CHA-sulfate. It seems that the changes did not result from the strong basicity but from a direct irritating action of $\mathrm{CHA}$ on the tissue.

In the values of $\mathrm{LD}_{30}$ of $\mathrm{CHA}$, somewhat 
higher value was obtained in Wistar strain male rats than in the same strain female, but there was no significant difference between both sexes statistically. In pregnant WistarImamichi strain rats, its $\mathrm{LD}_{b 0}(180.1 \mathrm{mg} / \mathrm{kg})$ was somewhat higher than that of nonpregnant female of the same strain. Taking into account the present experimental conditions, it is considerd that there exist little difference between the both $\mathrm{LD}_{\mathrm{so}}$ values.

In the teratological studies, the maternal weight gain and food and water consumptions were considerably suppressed following the administration of $36 \mathrm{mg} / \mathrm{kg}$ of CHA and 2 of 17 dams died after intoxication. However, at the dose of $71.6 \mathrm{mg} / \mathrm{kg}$ of CHA-sulfate equivalent to $36 \mathrm{mg} / \mathrm{kg}$ of $\mathrm{CHA}$, changes of these three parameters were comparable to those of the control and no toxic symptoms were found.

The pregnancy was maintained well in all groups including the dams survived at the highest dose of CHA, and no evidence of fetal death or immaturity in development as well as malformation to be related to $\mathrm{CHA}$ administration was obtained.

Tanaka ${ }^{\text {(),6) }}$ reported that sodium cyclamate was effective to kill embryos or to retard fetal development in mice, but Nees and Derse ${ }^{24}$, Fritz and $\mathrm{Hess}^{25)}$, Klotzche ${ }^{26)}$ and Lorke ${ }^{27)}$ found no deleterious effects in mice, rats and rabbits given sodium cyclamate during pregnancy.

At present, the toxic effect of cyclamate has

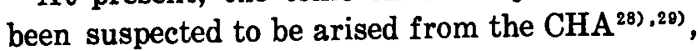
a metabolite produced in a metabolic process of cyclamate in the body. Kojima and Ichibagase ${ }^{\text {r) }}$ demonstrated that about $0.7 \%$ of ingested cyclamate was converted to CHA in dog and man. In the present investigation, though a large dose as about $1 / 5$ of $\mathrm{LD}_{\mathrm{so}}$ of $\mathrm{CHA}$ was given daily for 1 week including the critical period for organ development during pregnancy in rats, no effect on fetal development was observed. Furthermore, Takano and Suzuki ${ }^{80}$ ) found no effect of CHA on fetal development and no malformation in mice when 20 to 100 $\mathrm{mg} / \mathrm{kg}$ of CHA was orally given daily for 6 days from the day 6 to 11 of gestation, except some reduction in fetal weights at a dose of $100 \mathrm{mg} / \mathrm{kg}$. And also, other workers ${ }^{31), 82)}$ have noted that CHA has no deleterious effects on fetal development as well as no teratogenic effects in mice and rats when the agent was orally given for several days during pregnancy.

The reason of discrepancy between the Tanaka's findings and others still remains unknown at present, but our results support the reports of the investigators cited above that CHA was not embryotoxic or teratogenic when given its subtoxic doses to dams.

\section{References}

1) Brayan, G. T., Ertürk, E.: Science 167, 996 (1970).

2) Price, J. M., Biava, C. G., Oser, B. L., Vogin, E. E., Steinfeld, J., Ley, H. L.: ibid. 167, 1131 (1970).

3) Stoltz, D.R., Khera, K.S., Bendall, R., Gunner, S. W.: ibid. 167, 1501 (1970).

4) Stone, D., Lamson, E., Chang, Y.S., Pickering, K. W.: ibid. 164, 568 (1969).

5) Tanaka, R.: Jap. J. Puble. Health 11, 909 (1964) (in Japanese).

6) Tanaka, R.: J. Iwate Med. Ass. 16, 330 (1964) (in Japanese).

7) Kojima, S., Icibagase, H.: Chem. Pharm. Bull. (Tokyo) 14, 971 (1966).

8) Kojima, S., Ichibagase, H.: ibid. 16, 1851 (1968).

9) Leahy, J. S., Taylor, T., Rudd, G. J.: Fd. Cosmet. Toxicol. 5, 447 (1967).

10) Wills, J. H., Jameson, E., Stoewsand, G., Coulston, F.: Toxicol. Appl. Pharmacol. 12, 292 (1968).

11) Goldberg, L., Parekh, C., Patti, A., Soike, K.: ibid. 14, 654 (1969).

12) Davis, T. R. A., Adler, N., Opsahi, J. C.: ibid. 15, 106 (1969).

13) Oser, B. L., Carson, S., Vogin, E. E., Sonders, R. C.: Nature 220, 178 (1968).

14) Prosky, L., Odell, R. G.: J. Pharm. Sci. 60, 1341 (1971).

15) Wallance, W. C.,Lethco, E. J., Brouwer, E. A.: J. Pharmacol. Exp. Ther. 175, 325 (1970).

16) Asahina, M., Yamaha, T., Sarrazin, G., Watanabe, K.: Chem. Pharm. Bull. (Tokyo) 20, 102 (1972).

17) Legator, M. S., Palmer, K. A., Green, S., Peterson, K. W.: Science 165, 1139 (1969).

18) Pitkin, R. M., Reynolds, W. A., Filer, L. J.: Proc. Soc. Exp. Biol. Med. 132, 993 (1969).

19) Litchfield, J. T., Wilcoxon, F.: J. Pharmacol. Exp. Ther. 96, 99 (1949).

20) Wilson, J. G.: “Teratology" p. 262 (1965), Chicago Univ. Press, Chicago and London. 
21) Dawson, A. B.: Stain Tech. 1, 123 (1927).

22) Miyato, T., Kase, Y., Komikawa, Y., Kataoka, M., Kikuchi, K., Touchi, T.: Life Sci. 8, 843 (1969).

23) Lomonova, G. V.: Gigiena Trude Iprof. Zabolevaniga 7, 51 (1963).

24) Nees, P. O., Derse, R. H.: Nature 213, 1191 (1967).

25) Fritz, H., Hees, R.: Experientia 24, 1140 (1968).

26) Klotzche, C.: Arzneim.-Forsch. 19, 925 (1969).
27) Lorke, D.: ibid. 19, 920 (1969).

28) Rosenblum, I., Rosenblum, G.: Toxicol. Appl. Pharmacol. 12, 260 (1968).

29) Yamamura, H. I., Lee, I. P., Dixon, R. L.: J. Pharm. Sci. 57, 1132 (1968).

30) Takano, K., Suzuki, M.: Cong. Anom. 11, 51 (1971) (in Japanese).

31) Becker, B. A., Gibson, J. E.: Toxicol: Appl. Pharmacol. 17, 551 (1970).

32) Khera, K. S., Stoltz, D. R., Gunner, S. W., Lyon, D. A., Grice, H. C.: ibid. 18, 263 (1971). 